\title{
Characteristics in the components of the paprika by drying methods
}

\author{
Hyun-Suk Lee ${ }^{1}$, Ju$^{-}$Yeon Hong ${ }^{1}$, Young-Jun Choi ${ }^{2}$, Yang Suk Lee ${ }^{3}$, Su$^{-J e o n g}$ Seo $^{3}$, \\ Seung-Ryeul Shin ${ }^{1 *}$ \\ ${ }^{1}$ Faculty of Herbal Food Cuisine and Nutrition, Daegu Haany University, Gyeongsan 38610, Korea \\ ${ }^{2}$ Department of Food Beverage and Culinary Arts, Daegu Technical University, Daegu 42734, Korea \\ ${ }^{3}$ Department of Herbal Biotechnology, Daegu Haany University, Gyeongsan 38610, Korea
}

\begin{abstract}
The aim of this study was to investigate the characteristics of paprika dried by various methods. Moisture content of dried paprika was higher in vacuum freeze-dried red paprika (DRP) (11.85\%) than in vacuum freeze-drying of osmotic dried red paprika in sugar (RPS), vacuum freeze-drying of osmotic dried red paprika in fructose (RPF) and vacuum freeze-drying of osmotic dried red paprika in com syrup (RPCS). Carbohydrate content of DRP was the lowest among the dried groups, but fat, protein, and ash contents were the highest in DRP. The pH of paprika was the highest in RPF (5.34), while it was the lowest in DRP (5.05). Reducing sugar and sugar contents of RPF were $28.59 \mathrm{~g} / 100 \mathrm{~g}$ and $5.03{ }^{\circ}$ Brix, respectively, which are the highest level among the groups. All color values in inside of paprika were the highest in RPCS, while in outside of paprika, $L$ value is the highest in RPCS, and the value of a, $b$ were the highest in RPS. Regarding the texture characteristics of paprika, strongness, hardness, adhesiveness, chewiness and brittleness were the highest in RPS $(\mathbf{p}<0.05)$.
\end{abstract}

Key words : paprika, osmotic dried, vacuum freeze-dried, characteristics

\section{Introduction}

As lifespan has been extended due to the improvement of living standards in modern times, consumers are paying more attention to health and nutrition and the preference for natural foods and vegetarian diet is increasing (1). These changes have resulted in more physical strength and better nutrition. However the incidence of various diseases inducing cancer is still on the rise, of which important cause is known to be resulted from eating habits (2). The World Health Organization (WHO) recommends the consumption of fruits and vegetables rather than fish and meat, and indicates the intake of vegetables as an index of healthy eating habits. Neverthless according to the National Health Statistics of 2014, the intake of animal foods is high, while the intake

*Corresponding author. E-mail : shinsr@dhu.ac.kr

Phone : 82-53-819-1428, Fax : 82-53-819-1494

Received 10 July 2017; Revised 21 July 2017; Accepted 24 July 2017.

Copyright (c) The Korean Society of Food Preservation. All rights reserved. of vegetables and fruits is relatively less than the recommended intake, resulting in high nutritional and health concerns (3).

Paprika (Capsicum annuum L.) is an annual plant of solanaceae and chili pepper species which originate from central America. It also called paprika, sweet pepper, pimiento, or bell pepper depending on the country. It is classified as sweet pepper according to the glossary of the Korean Society for Horticultural Science (4). The origin of paprika is Central America. In Korea, Gangwon-do and Gyeongsangnam-do account for $71 \%$ of the total production area, in which Gangwon area shows a noticeable increase and steadily increasing trend $(5,6)$.

Paprika is strong in sweetness and rich in vitamin $\mathrm{C}$ without any spicy taste. It has varied colors such as green, yellow, and orange, and is mainly used as on ingredient for salads and stir-fry (7). As a warm-season crop, paprika is very sensitive to low temperatures. It is reported that according to the varieties, low-temperature disorders including accelerated aging, increase in softening of pulp, depression, maturity degradation and wrinkles are observed within the range of $0-10^{\circ} \mathrm{C}$, accomparying with secondary infection of fungus 
known as a spotty rot (8).

During the storage of paprika, microbial action and decomposition are reported to cause the loss of nutrients that are important to taste, flavor and health as well as to its original vivid colors.

Generally hydrothermal treatment and low temperature storage, chemical treatment (9), high pressure $\mathrm{CO}_{2}$ treatment (10). Other special pretreatment methods and management methods have been rarely studied (11).

Studies on the use of paprika have been performed on steamed rice cake (12), paprika juice (13), noodles with paprika powder (14), rice wine with paprika juice (15). the application as is powder through drying, a spice through juicing or as an additive material $(16,17)$.

The advantage of natural and vegetarian foods is that most of them can be consmmed fresh without cooking. However, negligence in the production and distribution process can lead to decline in marketability (18). In order to solve these problems, studies on increasing the quality of the production and storage of paprika have been mainly carried out in Korea (19).

Osmotic drying developed by Ponting et al. is a drying method that uses the osmotic effect by using salt or saccharides (20). It is a drying method that can lower the loss of flavor and taste due to heat, prevent discoloration and remove the sourness of fruit, and enhance palatability by improving sweetness (21). In order to obtain good quality and shorten the drying time when drying fruits and vegetables, osmotic drying is widely used as a pretreatment method before conventional drying methods such as hot air drying, vacuum drying and freeze drying $(22,23)$.

Therefore, the objectives of this study is to investigate the characteristics of red paprika such as general ingredients, physical properties, and functional components of paprika products dried by the combination of osmotic drying and vacuum freeze drying, and to present the possibility of processed foods using paprika to induce adivation of paprika of consuming it other than as raw.

\section{Materials and Methods}

\section{Materials}

In April 2016, fresh and bright red paprika (Capsicum annuum L.) was purchased from the National Agricultural Cooperative Federation. The test samples were washed with water and then dried on a shelf to remove water. The stalk ends and seeds were removed and the fruits were sliced into $2 \mathrm{~cm} \times 2 \mathrm{~cm}$ squares. Fructose (Krystar, Crystalline Fructose) was purchased from Krystar, and white sugar (white sage) and starch syrup (old syrup, Ottogi) were purchased from a general large-scale mart.

\section{Preparation of dried paprika}

For dried paprika, vacuum freeze-dried red paprika (DRP), vacuum freeze-drying of osmotic dried red paprika in sugar (RPS), vacuum freeze-drying of osmotic dried red paprika in fructose (RPF) and vacuum freeze-drying of osmotic dried red paprika in corn syrup (RPCS) were made.

For the osmotic dehydration, the materials were mixed well at the ratio shown in Table 1, then put in the zipper bag and left at room temperature for $24 \mathrm{~h}$, with overturning and mixing every hour. After $24 \mathrm{~h}$, the sugar water was removed through colander for $30 \mathrm{~min}$. The dehydrated paprika was poured in a container containing $3 \mathrm{~L}$ of distilled water, stirred 10 times, and rinsed. After draining for $30 \mathrm{~min}$ again, paprika was spread on a table, dried for $1 \mathrm{~h}$, and then vacuum freeze-dried for 7 days at $-90^{\circ} \mathrm{C}$ (FD8512, Ilshin, Dongducheon, Korea) after freezing for $24 \mathrm{~h}$ in a cryogenic freezer at $-80^{\circ} \mathrm{C}$ (MDF-U52V, Sanyo, Osaka, Japan).

Table 1. Formulation of dried red paprika

(g)

\begin{tabular}{ccccc}
\hline \multirow{2}{*}{ Sample $^{1)}$} & \multicolumn{4}{c}{ Components } \\
\cline { 2 - 5 } & Red paprika & Sugar & Fructose & Corn syrup \\
\hline NRP & 100 & - & - & - \\
\hline DRP & 100 & - & - & - \\
RPS & 100 & 100 & - & - \\
RPF & 100 & 50 & 50 & - \\
RPCS & 100 & 50 & - & 50 \\
\hline
\end{tabular}

${ }^{1)} \mathrm{NRP}$, natural red paprika; DRP, vacuum freeze-dried red paprika; RPS, vacuum freeze-drying of osmotic dried red paprika in sugar; RPF, vacuum freeze-drying of osmotic dried red paprika in sugar and fructose; RPCS, vacuum freeze-drying of osmotic dried red paprika in sugar and corn syrup.

\section{Analysis of general components}

The general components of paprika were analyzed according to AOAC method (24). That is, the moisture content was measured by the atmospheric pressure drying method and the crude protein content was measured by a Kjeldahl crude protein automatic analyzer (Foss Kjeltec ${ }^{\mathrm{TM}} 2300$, FOSS, Hengenes, Sweden). The crude fat content was measured according to the Soxhlet method. The fixed quantity of crude ash was measured by the direct ash method. Carbohydrate content (\%) was determined by subtracting moisture, crude 
protein, crude fat and crude ash content $\%$ from $100 \%$ of the total.

\section{Measurement of titratable acidity and $\mathrm{pH}$}

To measure the acidity, $90 \mathrm{~mL}$ of distilled water was added to $10 \mathrm{~g}$ of paprika sample (24). The mixture was grinded using a homogenizer (AM-7, Nihonseiki Kaisha, Osaka, Japan) and filtered in a $100 \mathrm{~mL}$ volumetric flask with filter paper (Whatman No. 4). Then, 3 drops of $1 \%$ phenolphthalein (OCI Company Ltd., Seoul, Korea) solution were added to $20 \mathrm{~mL}$ of diluted sample solution and titrated with $0.1 \mathrm{~N}$ $\mathrm{NaOH}$ standard solution. The amount of base used to neutralize the solution was recoreded and acidity was calculated. The $\mathrm{pH}$ was measured by $\mathrm{pH}$ meter (HM-25R, TOA-DKK, Tokyo, Japan) using the sample solution made by pouring $90 \mathrm{~mL}$ of distilled water into $10 \mathrm{~g}$ of paprika sample, mixing and grinding it with homogenizer (AM-7, Nihonseiki Kaisha) and filtering it with filter paper (Whatman No. 4) in a $100 \mathrm{~mL}$ volumetric flask.

\section{Hydration stability and moisture absorption rate}

Hydration stability was measured by Lee et al. (25). About 55-66 g samples was taken as initial samples before each drying process. The dried sample was completely immersed in $1 \mathrm{~L}$ of boiling distilled water for $10 \mathrm{~min}$ for rehydration and taken out. The surface water was removed, and the weight is measured. This was conducted three times and expressed as an average value.

Moisture absorption rate was measured according to Lee et al. (25). About 4 to $5 \mathrm{~g}$ of dried samples were thoroughly immersed in $1 \mathrm{~L}$ of boiling distilled water for $10 \mathrm{~min}$ to be rehydrated and taken out. The surface water was removed and the weight is measured. This was repeated two more times and expressed as an average value.

\section{Reducing sugar content and total sugar contents}

The reducing sugar content was measured according to the Somogyi-Nelson method (26). For the sample solution, $50 \mathrm{~mL}$ of distilled water is added to $2 \mathrm{~g}$ of the sample, grinded with a hand blender (HR1607, Philips, Guangdong, China) and centrifuged at 3,000 rpm for 10 min using a high speed refrigerated centrifuge (VS-24SMTI, Vision, Seoul, Korea). Then, the supernatant was filtered through a filter paper (Whatman No. 4) in a $100 \mathrm{~mL}$ volumetric flask After diluting this sample solution to the appropriate concentration, $0.5 \mathrm{~mL}$ of solution A with $1 \mathrm{~mL}$ of sample solution for each concentration at $25: 1$ is added and heated in boiling water for $20 \mathrm{~min}$, and cooled. After adding $1 \mathrm{~mL}$ of solution $\mathrm{C}$, spectrophotometer (U-2001, Hitachi, Tokyo, Japan) was used to measure the absorbance at $520 \mathrm{~nm}$. The calibration curves were prepared with glucose to calculate the reducing sugar of paprika and expressed as the mean value of 3 repeated measurements.

For sugar content, $90 \mathrm{~mL}$ of distilled water is added to $10 \mathrm{~g}$ of sample, grinded with homogenizer (AM-7, Nihonseiki Kaisha), and filtered with filter paper (Whatman No. 4) in a $100 \mathrm{~mL}$ volumetric flask and then rectified. The sugar content of the solution was measured with a sugar meter (PAL-3, ATAGO, Tokyo, Japan).

\section{Color value measurement}

Color is a very important factor visually for consumers who consume the product and plays a pivotal role in stimulating preference. The color value was measured with a Chroma meter (CR-200, Minolta, Tokyo, Japan) and this was expressed as Hunter value L (lightness), a (redness), and b (yellowness). The inside of paprika and the outside of paprika were measured 6 times respectively, and the standard plate measured at this time was shown as a mean value by measuring repeatedly 6 times according to the usage of the equipment.

\section{Measurement of physical properties}

The physical properties of paprika were measured using a Sun rheometer (COMPAC-100 II, Sun Scientific, Tokyo, Japan). Under the measurement conditions, the test type is mode 21 , distance $15 \mathrm{~mm}$, plunger diameter $300 \%$, adapter type number. 4, table speed $60 \mathrm{~mm} / \mathrm{m}$, and load cell (max) $2 \mathrm{~kg}$. The strength, hardness, adhesiveness, cohesiveness, cohesiveness, springiness, chewiness, and brittleness were measured 10 times repeatedly and expressed as a mean value.

\section{Statistical analysis}

All experiments were repeated at least 3 times and expressed as mean \pm SD. One-way analysis of variance (ANOVA) was performed using the SPSS 23.0 statistical program (Chicago, IL, USA) to verify the significance level at $\mathrm{p}<0.05$. The significant differences between the sample groups were analyzed by Duncan's multiple range test (28).

\section{Results and Discussion}

\section{Changes in general components}

Table 2 shows the results on general components of paprika 
dried by various methods. The moisture content of undried raw paprika was $92.86 \%$. DRP paprika and paprika in the osmotic drying group with freeze drying were $11.85 \%$ and 6.94-7.57\%, respectively. The decrease of moisture content in osmotic-combined dried samples seems to be due to the dehydration caused by osmostic process. According to the carbohydrate content of paprika, that of fresh paprika was the lowest at $6.47 \%$, contrary to the water content, the content of osmotic dehydration group was the highest, 90.02-90.65\% followed by $80.75 \%$ of DRP. RPCS showed the highest in carbohydrats content and the lowest in moisture content.. According to the crude protein content of paprika, DRP has the highest $(1.71 \%)$ and RPS has the second highest content of $0.65 \%$. Raw paprika, RPF, and RPCS had relatively low contents of $0.27-0.07 \%$. The crude fat of paprika showed that DRP $0.56 \%$ was the highest and raw paprika has the lowest content of $0.09 \%$ and the osmotic drying group has 0.25-0.32\%, which was between DRP and raw paprika. In the crude ash content, in paprika showed that the content of DRP (5.14\%) was higher than that of osmotic drying groups which show the content of $1.60-2.02 \%$. Park et al. (29) reported the quality and physiological activity of blueberries according to the drying method raw blueberry were moisture $86.52 \%$, carbohydrate $11.51 \%$, crude ash $0.20 \%$, crude fat $0.20 \%$, crude protein $1.64 \%$, freeze dried blueberry moisture $17.32 \%$, carbohydrate $77.02 \%$, crude fat $0.71 \%$, crude protein $3.84 \%$. Compared with these reports, the effect of freeze-drying on the general components in current study tended to be similar.

Table 2. General components content of the dried red paprika by drying methods

$(\%)$

\begin{tabular}{cccccc}
\hline \multirow{2}{*}{ Components } & \multicolumn{5}{c}{ Samples $^{1)}$} \\
\cline { 2 - 6 } & NRP & DRP & RPS & RPF & RPCS \\
\hline Moisture & $92.86 \pm 0.10^{2) a 3}$ & $11.85 \pm 1.66^{\mathrm{b}}$ & $7.25 \pm 0.47^{\mathrm{c}}$ & $7.57 \pm 1.25^{\mathrm{c}}$ & $6.94 \pm 0.81^{\mathrm{c}}$ \\
Carbohydrate & $6.47 \pm 0.19^{\mathrm{c}}$ & $80.75 \pm 2.08^{\mathrm{b}}$ & $90.02 \pm 0.84^{\mathrm{a}}$ & $90.42 \pm 1.78^{\mathrm{a}}$ & $90.65 \pm 1.17^{\mathrm{a}}$ \\
Crude protein & $0.27 \pm 0.02^{\mathrm{c}}$ & $1.71 \pm 0.04^{\mathrm{a}}$ & $0.65 \pm 0.07^{\mathrm{b}}$ & $0.16 \pm 0.06^{\mathrm{d}}$ & $0.07 \pm 0.04^{\mathrm{d}}$ \\
Crude lipid & $0.09 \pm 0.03^{\mathrm{b}}$ & $0.56 \pm 0.17^{\mathrm{a}}$ & $0.26 \pm 0.08^{\mathrm{b}}$ & $0.25 \pm 0.20^{\mathrm{b}}$ & $0.32 \pm 0.14^{\mathrm{b}}$ \\
Crude ash & $0.31 \pm 0.05^{\mathrm{d}}$ & $5.14 \pm 0.21^{\mathrm{a}}$ & $1.81 \pm 0.23^{\mathrm{bc}}$ & $1.60 \pm 0.27^{\mathrm{c}}$ & $2.02 \pm 0.19^{\mathrm{b}}$ \\
\hline
\end{tabular}

${ }^{11} \mathrm{NRP}$, natural red paprika; DRP, vacuum freeze-dried red paprika; RPS, vacuum freeze-drying of osmotic dried red paprika in sugar; RPF, vacuum freeze-drying of osmotic dried red paprika in sugar and fructose; RPCS, vacuum freeze-drying of osmotic dried red paprika in sugar and corn syrup.

${ }^{2)}$ All values are expressed as Mean \pm SD of triplicate determinations.

${ }^{3}$ Different superscripts within the column are significantly different at $p<0.05$ by Duncan's multiple range test.
Changes in hydration stability and moisture absorption rate

Table 3 shows the results of hydration stability and moisture absorption rate of paprika according to the drying methods. The hydration stability of DRP (25.93\%) showed the increase by $7 \%$ compared with that of osmotic dry group of $16.34-19.73 \%$. This seems to be due to the fact that the leaching of the solution in osmotic dried samples was higher than that of DRP, which was only freeze-dried. In moisture absorption of paprika, like hydration stability, the osmotic drying group had a relatively lower moisture absorption rate than DRP; DRP showed, $220.12 \%$ followed by RPCS $157.18 \%$, RPS $124.06 \%$, RPF $111.47 \%$. According to the study of Choi et al. (30) which showed the effect of the combination of osmotic drying and hot air drying on the quality of dried apple, the restorative power of the apple products subjected to osmotic dehydration decreased compared with the control group, and the restorative power was reported to decrease as the concentration of the immersion solution increased, which is a similar trend to this study.

Table 3. Rehydration rate and moisture absorption of the dried red paprika by drying methods

\begin{tabular}{ccc}
\hline Samples $^{1)}$ & Rehydration rate & Moisture absorption \\
\hline DRP & $25.93 \pm 0.48^{2) \text { a3 })}$ & $220.12 \pm 5.99^{\mathrm{a}}$ \\
RPS & $17.25 \pm 0.29^{\mathrm{c}}$ & $124.06 \pm 3.72^{\mathrm{c}}$ \\
RPF & $16.34 \pm 0.49^{\mathrm{c}}$ & $111.47 \pm 6.30^{\mathrm{c}}$ \\
RPCS & $19.73 \pm 1.00^{\mathrm{b}}$ & $157.18 \pm 13.02^{\mathrm{b}}$
\end{tabular}

${ }^{1)} \mathrm{DRP}$, vacuum freeze-dried red paprika; RPS, vacuum freeze-drying of osmotic dried red paprika in sugar; RPF, vacuum freeze-drying of osmotic dried red paprika in sugar and fructose; RPCS, vacuum freeze-drying of osmotic dried red paprika in sugar and corn syrup.

${ }^{2)}$ All values are expressed as Mean \pm SD of triplicate determinations.

${ }^{3)}$ Different superscripts within the column are significantly different at $p<0.05$ by Duncan's multiple range test.

\section{Changes in titratable acidity and $\mathrm{pH}$}

Table 4 shows the $\mathrm{pH}$ and acidity of paprika according to the drying methods. DRP showed the highest acidity (2.93\%) and RPF showed the lowest value (1.73\%). RPS and RPCS had the acidity of $2.72 \%$ and $2.22 \%$, respectively, and the raw paprika showed the lowest acidity $(0.80 \%)$. According to the results of $\mathrm{pH}$ of paprika, RPF showed the highest $\mathrm{pH}, 5.34$ followed by RPS 5.31, RPCS 5.25, raw paprika 5.10, and DRP 5.05. Generally, paprika by drying had the value of about $\mathrm{pH} 5$ and was slightly acidic.

The study of Moon (31) who studied the quality of Cheongpomuk (mung bean jelly) containing lotus leaf powder 
showed that $\mathrm{pH}$ and activity of freeze-dried lotus leaf powder for each region were different. In the effect of osmotic drying and vacuum infusion on the quality of apple Choi et al. (32) reported that the acidity of the osmotic dried apple has dropped more than twice compared with the control group; $151.2 \%$ in the control group to $61.4 \%$ in the osmotic dried group. This is because when the osmotic drying treatment is performed, a large amount of apple organic acid is eluted into the external sugar solution due to osmotic pressure, which is similar with the results of this study.

Table 4. Titratable acidity and $\mathrm{pH}$ of the dried red paprika by drying methods

\begin{tabular}{ccc}
\hline Samples $^{1)}$ & Titratable acidity $(\%)$ & $\mathrm{pH}$ \\
\hline NRP & $0.80 \pm 0.09^{2)(3)}$ & $5.10 \pm 0.03^{\mathrm{c}}$ \\
DRP & $2.93 \pm 0.08^{\mathrm{a}}$ & $5.05 \pm 0.02^{\mathrm{d}}$ \\
RPS & $2.72 \pm 0.03^{\mathrm{b}}$ & $5.31 \pm 0.02^{\mathrm{a}}$ \\
RPF & $1.73 \pm 0.08^{\mathrm{d}}$ & $5.34 \pm 0.03^{\mathrm{a}}$ \\
RPCS & $2.22 \pm 0.08^{\mathrm{c}}$ & $5.25 \pm 0.02^{\mathrm{b}}$ \\
\hline
\end{tabular}

${ }^{1)} \mathrm{NRP}$, natural red paprika; DRP, vacuum freeze-dried red paprika; RPS, vacuum freeze-drying of osmotic dried red paprika in sugar; RPF, vacuum freeze-drying of osmotic dried red paprika in sugar and fructose; RPCS, vacuum freeze-drying of osmotic dried red paprika in sugar and corn syrup.

${ }^{2}$ All values are expressed as Mean \pm SD of triplicate determinations.

${ }^{3}$ Different superscripts within the column are significantly different at $p<0.05$ by Duncan's multiple range test.

\section{Changes of reducing sugar and Brix}

Table 5 shows the results of measuring reducing sugar and brix contents of paprika by drying methods. RPF showed the highest content of $28.59 \mathrm{~g} / 100 \mathrm{~g}$ followed by DRP 22.26 g/100 g, RPS 20.76 g/100 g, RPCS 19.33 g/100 g, raw paprika $7.33 \mathrm{~g} / 100 \mathrm{~g}$. When comparing RPF $28.59 \mathrm{~g} / 100 \mathrm{~g}$ with RPCS $19.33 \mathrm{~g} / 100 \mathrm{~g}$ with the lowest content in the osmotic drying group, the difference of $9.26 \mathrm{~g} / 100 \mathrm{~g}$ was shown. Sugar

Table 5. Reducing sugar and brix contents of the dried red paprika by drying methods

\begin{tabular}{ccc}
\hline Samples $^{1)}$ & Reducing sugar (g/100 g) & ${ }^{\circ}$ Brix \\
\hline NRP & $7.33 \pm 1.26^{2) \mathrm{d} 3)}$ & $0.62 \pm 0.03^{\mathrm{e}}$ \\
DRP & $22.26 \pm 0.99^{\mathrm{b}}$ & $4.17 \pm 0.06^{\mathrm{c}}$ \\
RPS & $20.76 \pm 0.84^{\mathrm{bc}}$ & $4.73 \pm 0.06^{\mathrm{b}}$ \\
RPF & $28.59 \pm 1.05^{\mathrm{a}}$ & $5.03 \pm 0.06^{\mathrm{a}}$ \\
RPCS & $19.33 \pm 0.22^{\mathrm{c}}$ & $4.00 \pm 0.10^{\mathrm{d}}$ \\
\hline
\end{tabular}

${ }^{1)} \mathrm{NRP}$, natural red paprika; DRP, vacuum freeze-dried red paprika; RPS, vacuum freeze-drying of osmotic dried red paprika in sugar; RPF, vacuum freeze-drying of osmotic dried red paprika in sugar and fructose; RPCS, vacuum freeze-drying of osmotic dried red paprika in sugar and corn syrup.

${ }^{2)}$ All values are expressed as Mean \pm SD of triplicate determinations.

${ }^{33}$ Different superscripts within the column are significantly different at $p<0.05$ by Duncan's multiple range test. content raw paprika showed $0.62{ }^{\circ}$ Brix and RPF showed the highest ${ }^{\circ}$ Brix of 5.03 followed by RPS $4.73{ }^{\circ}$ Brix, DRP 4.17 ${ }^{\circ}$ Brix, RPCS $4.00{ }^{\circ}$ Brix. In the study on the quality characteristics of domestic Hanbarong jam with fructo oligosaccharides and isomaltooligosaccharides, Choi et al. (33) reported that reducing sugar increased significantly as the addition of fructose increased, which was consistent with the results of this study.

\section{Changes in color value}

Table 6 shows the results of the color value of paprika by drying methods. In the inside of paprika, L values of RPCS, RPS and raw paprika were 61.55, 55.98 and 55.55, respectively, showing higher value than RPF 46.14 and DRP 31.28. Similarly, in the outside of paprika, $L$ values of RPCS, RPS and raw paprika are 44.52, 40.39 and 39.71, respectively, which were higher than RPF 36.92 and DRP 30.16. The inside of paprika is generally brighter than the outside of paprika by showing higher $\mathrm{L}$ value.

In the inside of paprika, RPCS had the highest a value of 31.45 and DRP showed the lowest value of 23.70 and in the outside of paprika, RPS of 45.40 was the highest value and DRP of 23.10 was the lowest. Therefore, the outside of paprika is strong than the inside of paprika in redness.

In the inside of paprika, RPCS, RPS, raw paprika, RPF and DRP showed $b$ values of 36.09, 33.94, 29.92, 22.48 and 12.07 , respectively and in the outside, RPS, RPCS, RPCS,

Table 6. Hunter's color value of the dried red paprika by drying methods

\begin{tabular}{ccccc}
\hline \multirow{2}{*}{ Samples $^{1)}$} & \multicolumn{3}{c}{ Hunter color value } \\
\cline { 2 - 5 } & NRP & $55.55 \pm 2.24^{2) b 3)}$ & $29.48 \pm 3.03^{\mathrm{a}}$ & $29.92 \pm 1.48^{\mathrm{b}}$ \\
& DRP & $31.28 \pm 1.64^{\mathrm{d}}$ & $23.70 \pm 2.72^{\mathrm{b}}$ & $12.07 \pm 1.92^{\mathrm{d}}$ \\
Inside & RPS & $55.98 \pm 1.61^{\mathrm{b}}$ & $30.93 \pm 1.82^{\mathrm{a}}$ & $33.94 \pm 2.14^{\mathrm{a}}$ \\
& RPF & $46.14 \pm 3.17^{\mathrm{c}}$ & $31.03 \pm 2.53^{\mathrm{a}}$ & $22.48 \pm 2.11^{\mathrm{c}}$ \\
& RPCS & $61.55 \pm 2.02^{\mathrm{a}}$ & $31.45 \pm 2.93^{\mathrm{a}}$ & $36.09 \pm 2.77^{\mathrm{a}}$ \\
\hline \multirow{4}{*}{ Outside } & NRP & $39.71 \pm 1.70^{\mathrm{b}}$ & $33.04 \pm 1.83^{\mathrm{c}}$ & $10.33 \pm 1.66^{\mathrm{d}}$ \\
& DRP & $30.16 \pm 1.56^{\mathrm{d}}$ & $23.10 \pm 2.52^{\mathrm{d}}$ & $9.19 \pm 1.90^{\mathrm{d}}$ \\
& RPS & $40.39 \pm 2.92^{\mathrm{b}}$ & $45.40 \pm 1.67^{\mathrm{a}}$ & $27.19 \pm 2.77^{\mathrm{a}}$ \\
& RPF & $36.92 \pm 0.98^{\mathrm{c}}$ & $37.86 \pm 1.56^{\mathrm{b}}$ & $16.81 \pm 2.28^{\mathrm{c}}$ \\
& RPCS & $44.52 \pm 2.46^{\mathrm{a}}$ & $43.89 \pm 1.27^{\mathrm{a}}$ & $22.78 \pm 3.75^{\mathrm{b}}$ \\
\hline
\end{tabular}

${ }^{1)} \mathrm{NRP}$, natural red paprika; DRP, vacuum freeze-dried red paprika; RPS, vacuum freeze-drying of osmotic dried red paprika in sugar; RPF, vacuum freeze-drying of osmotic dried red paprika in sugar and fructose; RPCS, vacuum freeze-drying of osmotic dried red paprika in sugar and corn syrup.

${ }^{2)}$ All values are expressed as Mean \pm SD of triplicate determinations.

${ }^{3)}$ Different superscripts within the column are significantly different at $p<0.05$ by Duncan's multiple range test. 
raw paprika and DRP showed 27.19, 22.78, 16.81, 10.33 and 9.19 , respectively, showing the higher yellowness in the inside of paprika. The color of dried paprika was clearer and brighter than that of only freeze-dried paprika during osmotic drying. Especially, RPCS had a higher value than RPS and RPF.

Kang et al. (34) reported that the color values of paprika were measured as $\mathrm{L}$ value of 30.75 , a value of 23.27 , b value of 11.38. Ha et al. (35) investigated the effect of shading method on growth and fruit characteristics when harvesting paprika during summer and reported that the color values of paprika outside were measured as $\mathrm{L}$ value of 36.4 , a value of $34.3, \mathrm{~b}$ value of 18.9. Above study seems to be somewhat different from the results of this study but similar color values are shown.

When the color of raw paprika in this study was compared with the results of the studies of Kang et al. (34) and Ha et al. (35), differences were observed such as the variety, temperature, and cultivation area of paprika and temperature. Based on the color of paprika samples, which has also undergone osmotic dehydration is clearer and brighter. When developing processed foods of paprika, research and development considering this part will lead to products with better merchandise.

\section{Changes in texture}

Table 7 shows the results of texture measurement of paprika by drying methods. Strongness of RPS was the highest, 15.11 $\mathrm{kg} / \mathrm{cm}^{2}$ and that of raw paprika was $11.45 \mathrm{~kg} / \mathrm{cm}^{2}$. Strongness of RPF and RPCS was $6.19 \mathrm{~kg} / \mathrm{cm}^{2}$ and $6.94 \mathrm{~kg} / \mathrm{cm}^{2}$, respectively, showing the difference of more than twice compared to RPS. DRP showed the lowest strongness of 4.00 $\mathrm{kg} / \mathrm{cm}^{2}$.
Hardness of RPS and raw paprika was $12.28 \mathrm{~kg} / \mathrm{cm}^{2}$ and $8.44 \mathrm{~kg} / \mathrm{cm}^{2}$, respectively, showing higher value than the other groups. RPCS and RPF showed similar values, $4.37 \mathrm{~kg} / \mathrm{cm}^{2}$ and $4.44 \mathrm{~kg} / \mathrm{cm}^{2}$, respectively which were three times lower than RPS. DRP showed the lowest of $2.89 \mathrm{~kg} / \mathrm{cm}^{2}$.

As with strongness and hardness, RPS showed the highest adhesiveness of $358.00 \mathrm{~g}$ followed by RPCS (248.00 g). Adhesiveness of RPF and DRP were $135.00 \mathrm{~g}$ and 122.80 $\mathrm{g}$, respectively, showing the values of about three times lower than RPS and about two times lower than RPCS. Raw paprika showed the lowest adhesiveness of 75.33. DRP showed the highest cohesiveness of $35.43 \%$, and RPC and raw paprika showed high values of $34.63 \%$ and $33.27 \%$, respectively. That of RPF was $27.18 \%$ and RPS showed the lowest value of $22.39 \%$.

Four groups except RPS had similar springiness of 89.91-95.68\% and RPS showed a value as low as $77.67 \%$. Chewiness of RPS was the highest, $239.01 \mathrm{~g}$ and DRP showed the lowest value of $99.73 \mathrm{~g}$. In brittleness, RPS and DRP had values of $189.98 \mathrm{~g}$ and $95.53 \mathrm{~g}$, respectively.

Putting these results together, when paprika was freeze-dried, it is softened because hardness decreased. When osmotic drying is carried out together, RPF and RPCS showed a tendency of being soft because hardness decreased and stickiness increased due to sugar.

\section{Conclusions}

Carbohydrate content was high in dried group, but fat and crude ash content were high in DRP. Rehydration rate of vacuum infiltrated paprika was ranged from $16.34 \%$ to

Table 7. Texture characteristics of the dried red paprika by drying methods

\begin{tabular}{cccccc}
\hline \multirow{2}{*}{ Texture parameters } & \multicolumn{5}{c}{ Samples } \\
\cline { 2 - 5 } & NRP & DRP & RPS & RPF & RPCS \\
\hline Strongness $\left(\mathrm{kg} / \mathrm{cm}^{2}\right)$ & $11.45 \pm 0.70^{2 \mathrm{~b}) \mathrm{b3})}$ & $4.00 \pm 0.25^{\mathrm{e}}$ & $15.11 \pm 0.59^{\mathrm{a}}$ & $6.19 \pm 0.41^{\mathrm{d}}$ & $6.94 \pm 0.08^{\mathrm{c}}$ \\
Hardness $\left(\mathrm{kg} / \mathrm{cm}^{2}\right)$ & $8.44 \pm 0.55^{\mathrm{b}}$ & $2.89 \pm 0.29^{\mathrm{d}}$ & $12.28 \pm 1.69^{\mathrm{a}}$ & $4.44 \pm 0.37^{\mathrm{c}}$ & $4.37 \pm 0.32^{\mathrm{c}}$ \\
Adhesiveness (g) & $75.33 \pm 11.15^{\mathrm{d}}$ & $122.80 \pm 16.99^{\mathrm{c}}$ & $358.00 \pm 27.54^{\mathrm{a}}$ & $135.00 \pm 16.60^{\mathrm{c}}$ & $248.00 \pm 26.70^{\mathrm{b}}$ \\
Cohesiveness (\%) & $33.27 \pm 1.93^{\mathrm{a}}$ & $35.43 \pm 4.28^{\mathrm{a}}$ & $22.39 \pm 5.95^{\mathrm{b}}$ & $27.18 \pm 2.34^{\mathrm{b}}$ & $34.63 \pm 4.18^{\mathrm{a}}$ \\
Springiness (\%) & $94.40 \pm 1.48^{\mathrm{a}}$ & $95.68 \pm 3.48^{\mathrm{a}}$ & $77.67 \pm 7.19^{\mathrm{b}}$ & $89.91 \pm 6.53^{\mathrm{a}}$ & $90.91 \pm 1.26^{\mathrm{a}}$ \\
Chewiness (g) & $119.84 \pm 13.07^{\mathrm{c}}$ & $99.73 \pm 5.86^{\mathrm{c}}$ & $239.01 \pm 37.47^{\mathrm{a}}$ & $118.99 \pm 13.39^{\mathrm{c}}$ & $169.85 \pm 13.60^{\mathrm{b}}$ \\
Brittleness (g) & $113.26 \pm 14.11^{\mathrm{c}}$ & $95.53 \pm 8.51^{\mathrm{c}}$ & $189.98 \pm 35.44^{\mathrm{a}}$ & $108.12 \pm 17.29^{\mathrm{c}}$ & $154.51 \pm 13.60^{\mathrm{b}}$ \\
\hline
\end{tabular}

${ }^{11} \mathrm{NRP}$, natural red paprika; DRP, vacuum freeze-dried red paprika; RPS, vacuum freeze-drying of osmotic dried red paprika in sugar; RPF, vacuum freeze-drying of osmotic dried red paprika in sugar and fructose; RPCS, vacuum freeze-drying of osmotic dried red paprika in sugar and corn syrup.

${ }^{2)}$ All values are expressed as Mean \pm SD of triplicate determinations.

${ }^{3)}$ Different superscripts within the column are significantly different at $p<0.05$ by Duncan's multiple range test. 
$19.73 \%$, showed the highest in DRP (25.93\%). Moisture reabsorption rate was the highest in DRP (220.12\%). The $\mathrm{pH}$ of paprika was the highest in RPF (5.34), while it was the lowest in DRP (5.05). Reducing sugar content of RPF was as high as $28.59 \mathrm{~g} / 100 \mathrm{~g}$, and its sugar content was the highest as $5.03{ }^{\circ}$ Brix. The $\mathrm{L}$ values of surfaces of inside and outside of paprika were all high in RPCS, and average a value was high outside, while average $b$ value was high inside. Regarding the texture of paprika, strongness, hardness, adhesiveness, chewiness, and brittleness were the highest in RPS ( $\mathrm{p}<0.05$ ). Thus, this study may contribute to development of processed food and health functional food with dried paprika, promoting the activation of paprika market.

\section{References}

1. Kim SY, You JS, Chang KJ (2013) Consumption of health functional food and dietary habits, nutrient intake and dietary quality of college students in Incheon. Korean J Nutr, 46, 166-176

2. Choe JS, Ji SM, Paik HY, Hong SM (2003) A study on the eating habits and dietary consciousness of adults in urban area. J Korean Soc Food Sci Nutr, 32, 1132-1146

3. Lee KA (2015) Comparisons of the eating habit, preferences and intake frequency of vegetables between middle and high school students in Busan. J Korean Home Economics Education Assciation, 27, 93-107

4. Hwang JH, Jang MS (2001) Effect of paprika (Capsicum annuum L.) juice on the acceptability and quality of wet noodle ( I ). Korean J Food Cook Sci, 17, 373-379

5. Lee JD, Do JW, Han JH, An CG, Kweon OY, Kim YK, Yoon JB (2011) Allelism and molecular marker tests for genic male sterility in paprika cultivars. Kor J Hort Sci Technol, 29, 130-134

6. Jo SJ, Wi TS (2016) Analysis for paprika production and consumption patterns. Horticulture abstracts, 140

7. Lee JW (1998) Crop cultivation-techniques of cultivation and quality management for sweet pepper. Protected Horticulture and Plant Factory, 11, 17-28

8. Choi IL, Lee YB, Kim IS, Baek JP, Kang HM (2013) Effect of several treatments on chilling injury of paprika fruits during low temperature storage. Protected Horticulture and Plant Factory, 22, 427-431

9. Choi IL, Son JS, Kim IS, Lee YB, Kang HM (2012) Effect of 1-MCP (1-methylcyclopropene) treatment on the quality and storability of paprika fruit during storage.
J Agri Life Environ Sci, 24, 43-49

10. Calvo L, Torres E (2010) Microbial inactivation of paprika using high pressure CO2. J Supercrit Fluid, 52, 134-141

11. Choi IL, Jung HJ, Kim IS, Kang HM (2009) Effect of hot water treatments on storability of fresh cut paprika processed by disorder fruits. J Agric Life Sci, 21, 1-7

12. Cho MS, Lee JS, Hong JS (2008) Quality characteristics of Sulgidduk with paprika. Korean J Food Cook Sci, 24, 333-339

13. Jung JY, Choi MH, Hwang JH, Chung HJ (2004) Quality characteristics of Jeung-Pyun prepared with paprika juice. J Korean Soc Food Sci Nutr, 33, 869-874

14. Jeong CH, Kim JH, Cho JR, Ahn CG, Shim KH (2007) Quality characteristics of wet noodles added with Korean paprika powder. J Korean Soc Food Sci Nutr, 36, 779-784

15. Kim SH, Park JM, Yoon HS, Song DN, Song IG, Eom HJ (2013) Physiological and sensory characteristics of Makgeolli with added paprika (Capsicum annuum L.). Korean J Food Sci Technol, 45, 578-582

16. Staack N, Ahrne L, Borch E, Knorr D (2008) Effect of infrared heating on quality and microbial decontamination in paprika powder. J Food Eng, 86, 17-24

17. Topuz A. Dincer C, Ozdemir KS, Feng H, Kushad M (2011) Influence of different drying methods on carotenoids and capsainoids of paprika (Cv., Jalapeno). Food Chem, 129, 860-865

18. Shin JK (2010) High intensity pulsed light treatment for preservation and shelf-life extension of seafoods. ARPC Report No. 11-1541000-000776-01

19. Kim HC, Ku YG, Lee JH, Kang JG, Bae JH (2012) Comparison plant growth and fruit setting among sweet pepper cultivars of red line. J Bio-Environment Control, 21, 247-251

20. Ponting JD, Watters GG, Forrey RR, Jackson R, Stanley WR (1966) Osmotic dehydration of fruits. Food Technol, 20, $1365-1368$

21. Na KM, Hong JH, Cha WS, Park JH, Oh SL, Cho YJ, Lee WY (2004) Optimization of osmotic dehydration process for manufacturing a dried sweet pumpkin. J Korean Soc Food Sci Nutr, 33, 433-438

22. Monsalve-Gonzalez A, Barbosa-Canovas GV, Cavalieri RP (1993) Mass transfer and textural changes during processing of apples by combined methods. J Food Sci, 58, 1118-1124

23. Reppa A, Mandala J, Kostaropoulos AE, Saravacos GD 
(1999) Influence of solute temperature and concentration on the combined osmotic and air drying. Drying Technol, $17,1449-1458$

24. AOAC (1990) Official Methods Analysis. $13^{\text {th }}$ ed, Association of Official Analytical Chemists, Washington DC, USA, p 125-132

25. Lee MK, Kim SH, Ham SS, Lee SY, Chung CK, Kang IJ, Oh DH (2000) The effect of far infrared ray-vacuum drying on the quality changes of Pimpinella bracycarpa. J Korean Soc Food Sci Nutr, 29, 561-567

26. Nelson N (1994) A photometric adoptation of the Somogyi method for determination of glucose. J Biol Chem, 153, 375-380

27. Park BH, Joo HM, Cho HS (2014) Quality characteristics of dried noodles added with Ligularia fischeri powder. Korean J Food Culture, 29, 205-211

28. Duncan DB (1955) Multiple range and multiple test. Biometeics, 11, 1-42

29. Park SJ, Choi YB, Ko JR, Rha YA, Lee HY (2014) Effects of drying methods on the quality and physiological activities of blueberry (Vaccinium ashei). Korean J Culinary Res, 20, 55-64
30. Choi HD, Lee HC, Kim YS, Choi IW, Park YK, Seog HM (2008) Effect of combined osmotic dehydration and hot-air drying on the quality of dried apple products. Korean J Food Sci Technol, 40, 36-41

31. Moon JH (2013) Properties of regional lotus leaf and quality characteristics of Cheongpomook with lotus powder. MS Thesis, Sejong University, Korea, p 34-35

32. Choi HD, Lee HC, Kim YS, Choi IW, Park YK, Seog HM (2008) Effect of osmotic dehydration and vacuum impregnation on the quality of dried apple. Korean J Food Sci Technol, 40, 178-183

33. Choi SR, Park HJ, Jin HH (2014) Quality characteristics of Tangor jam including fructo oligosaccharide and isomalto oligosaccharide. Korean J Culinary Res, 20, 223-234

34. Kang JH, Park SM, Kim HG, Son HJ, Song KJ, Cho MA, Kim JR, Lee JY, Song KB (2015) Gaseous chlorine dioxide treatment to produce high quality paprika for export. J Korean Soc Food Sci Nutr, 44, 1072-1078

35. Ha JB, Lim CS, Kang HY, Kang YS, Hwang SJ, Mun HS, An CG (2012) Effect of shading methods on growth and fruit quality of paprika in summer season. $\mathbf{J}$ Bio-Environment Control, 21, 419-427 